\title{
ESCOLA... ESPAÇOS DE FORMAÇÃO E DE APRENDERES
}

Esta edição estreia uma nova sessão na revista: Opinião. Entendemos que é de extrema importância no cenário que vivemos na educação brasileira mantermos espaço para interlocução e estímulo ao debate sobre temas relevantes e atuais. Na inauguração desta sessão, Gaudêncio Frigotto nos leva a refletir sobre uma questão bastante atual por meio do escrito intitulado "Escola sem partido": imposição da mordaça aos educadores. Antes, porém, como tradicionalmente fazemos na primeira edição de cada ano, na sessão Entrevista, Helena Araújo conversa com o Professor Marcelo Andrade da PUC-Rio sobre pesquisa, sua importância na escola de ensino fundamental, aprendizagens e formação de professores. A sessão Artigos se inicia com Ivonei Andrioni apresentando a organização do projeto político pedagógico e do projeto de educação profissional em Administração Rural Integrada ao Ensino Médio de uma escola pública do campo, localizada no estado do Mato Grosso, região Centro-Oeste do Brasil. Andrioni ancora-se na perspectiva crítico-dialética ou materialista histórico-dialética e busca conhecer "como os princípios da escola unitária, da formação omnilateral e politécnica estão presentes no cotidiano da escola", além de outros aspectos. Assim, busca conhecer e analisar as possibilidades e fragilidades presentes. O segundo artigo, de autoria de Maria Cristina da Rosa Fonseca da Silva e Regina Finck Schabeck dedica-se a compreender como são feitas adaptações curriculares por professores de Música e de Artes Visuais para promoção da inclusão escolar de crianças com deficiências sensoriais, auditivas e visuais, garantindo-se igualdade de acesso e respeito às diferenças. As autoras pretendem fortalecer políticas de pesquisa que contribuam para a existência de mudanças no currículo do ensino das Artes com vistas à promoção da inclusão. Marcelo da Cunha Matos analisa os sentidos da Educação Física presentes na produção acadêmica publicada em periódicos classificados pelo critério Qualis/CAPES, tendo como recorte a Educação Infantil e os primeiros anos do Ensino Fundamental, bem como os impactos desses sentidos produzidos na formação inicial do professor de Educação Física na UERJ. A reflexão sobre a importância dos museus como espaços de educação não formal é apresentada por Mônica Miranda Souto Ribeiro, que analisa a dimensão educativa dos museus por meio das relações entre memória, história, poder e identidade. O quinto artigo traz a contribuição de Sérgio Ricardo Oliveira por meio de estudo sobre educação e disciplina no contexto moderno, fundamentado na obra de Michel Foucault, principalmente em "Vigiar e Punir" (1975). Para encerrar esta edição, Andrea da Paixão Fernandes contribui com a sessão Resenhas ao apresentar o livro "Ensaios de Imagens: cidades", organizado por Gianne Chagastelles, composto por ensaios que se propõem a pensar a cidade por suas múltiplas facetas, histórias e memórias.

Ótima leitura!

Andrea da Paixão Fernandes

Débora de Aguiar Lage 